\title{
Preparing Administrators To Serve Diverse Populations Of Students With Learning Challenges
}

Ronald A. Styron, Jr., (Email: Ronald.Styron@usm.edu), University of Southern Mississippi Wanda S. Maulding, (Email: wanda.maulding@usm.edu), University of Southern Mississippi Gaylynn A. Parker (Email: gaylynn.parker@usm.edu), University of Southern Mississippi

\begin{abstract}
The notion of integrating a curriculum is more than connecting pieces so that students can see the bigger design - in effective curriculum integration models, knowledge is meaningfully related and connects in such a way that it is relevant to other areas of learning as well as to real life (Morris, 2003). This work details the integrated efforts of two university departments, The Department of Educational Leadership and Research (ELR) and The Department of Curriculum, Instruction and Special Education (CISE), to restructure a school administrators' preparation program to better prepare leadership candidates for meeting the challenges of student diversity relative to P-12 students with learning disabilities. This university was located in the southern region of the United States in a state with significant levels of students from diverse populations with special learning needs. A modified action research model was used as the conceptual framework to accomplish this undertaking.
\end{abstract}

\section{INTRODUCTION}

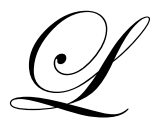

eaders in education have sought to improve the quality of special needs' services for diverse populations of disabled students through an array of reform efforts in response to increasing school accountability. The No Child Left Behind Act of 2001 (NCLB) is the most recent of these efforts. While meeting with limited resistance from some educators, accountability movements have been based upon principles of valuing individuals and promoting opportunities for children. Thus, accountability programming requires today's administrators to develop and maintain a vision of excellence in educational service delivery, be able to successfully collaborate with teachers, parents, and community members, and provide evidence of academic improvement within each school (DiPaola \& Walther-Thomas, 2003).

\section{THE ROLE OF SCHOOL LEADERS RELATIVE TO DIVERSITY}

Increasing numbers of diverse populations of students with learning disabilities are receiving instruction in the general education classroom. The underlying presumption fueling this trend of including diverse students with disabilities in the general education classroom is that receiving instruction with their typically developing peers will help meet the goal of equity in student achievement levels (Cohen, Forgan, Klinger Schumm, \& Vaughn, 1998; Yell \& Schriner, 1997). However, mere physical placement in the general education classroom is not sufficient and certainly will not result in all students mastering proficiency on grade-level assessments (Baker, Wang, \& Walberg, 1994; Rallis \& Anderson, 1998; Vaughn, Schumm, Klinger, \& Saumell, 1995). Successful instruction in general education settings requires adaptations and modifications in existing teaching practices to meet the educational needs of students with disabilities, and administrators have the grave responsibility of ensuring that these students receive appropriate services. At the foundation of providing an appropriate education for students with disabilities is creating an overall school vision of acceptance of diverse populations with special needs. 


\section{Creating A Vision}

Perhaps the most challenging role administrators must fill is that of inspiring a common vision among staff members. Considering the prevalent negativity that pervades inclusive education, creating and accepting an appropriate vision regarding the appreciation for and acceptance of student diversity is exceedingly difficult. A major obstacle to joining people in a common vision regarding special populations is that many teachers and administrators tend to focus on the disabilities or learning levels of children relative to their diverse backgrounds, rather than the individuality and strengths that each child possesses (Rallis \& Anderson, 1998). The age of teachers objecting to instructing students with disabilities from diverse populations is over, but the 'ableist' attitude remains (Hehir, 2003). In light of this phenomenon, administrators must first believe in the power of the individual student and then model this understanding of diversity to meet children's challenging learning needs.

\section{Collaboration}

Administrators have always been responsible for overseeing the collaboration of professionals involved in providing educational services for culturally diverse students with disabilities. Without effective, ongoing collaboration among administrators, parents, general and special education teachers, and other professionals included in a student's Individual Education Plan (IEP) committee, the provision of appropriate instruction cannot be ensured. In fact, collaboration is essential to successful special educational services. Alternatives to conventional wisdom about how populations of diverse disabled students can and should learn--such as an early emphasis on higher-order tasks, meaning and understanding, and cooperative learning--require teachers to structure their lessons differently and alter fundamental beliefs about learning. Change of this magnitude cannot happen without adequate support systems, especially administrative support (USDE, 1995).

To ensure ongoing collaboration, administrators must provide time for general and special educators to meet (Vaughn \& Schumm, 1995, Villa \& Thousand, 2003). General educators are often very knowledgeable about curriculum and content, but not trained in methods for adapting instruction for diverse student populations with special needs (Vaugh \& Schumm, 1994). Special education teachers have experience adapting and individualizing instruction. Thus, it is crucial for these professionals to collaborate on specific student needs and methods of effective practice.

Another essential component of providing adequate educational services to diverse student populations with disabilities is successful collaboration between administrators and parent advocates. This can be an area of contention for many administrators as they often report feeling inundated with legal and instructional responsibilities. Additionally, they report that parent advocates do not understand their position and economic limitations in serving the needs of these students. Parent advocates report feeling unheard and unappreciated by administrative staff members.

Zaretsky (2004) describes elements of collaboration between administrative staff and parent advocates that lead to both successful and unsuccessful results. Zaretsky further presents several facilitating strategies as a framework of beneficial behaviors, i.e., empathizing, clarifying, and communicating honestly and openly regarding both diverse populations and special education agendas. Another major component of successful collaboration is careful listening including eye contact, nodding, and smiling.

Unsuccessful collaboration (Zaretsky, 2004) includes forceful personal and political agendas, mistrust, feelings of a lack of appreciation for others' views, demands, abusive language, and unwillingness to compromise. Feeling unheard and unimportant and blaming financial constraints for inadequate services are also cited as elements of unsuccessful collaboration.

Thus, the concept of "taking a village to rear a child" makes the need for school administrators to know how to assist school communities in educating diverse populations of special needs students imperative. 


\section{Professional Development}

Unless general education teachers receive training in methods for teaching diverse populations with special needs, administrators cannot ensure that these students will receive an appropriate education. The heart of the inclusion debate is not whether students with disabilities are ready to join their typically developing peers, but whether teachers are ready to implement instructional adaptations and strategies necessary for students with disabilities to be successful (Crockett \& Kauffman, 1998, Imas, 2004). Students with special needs from diverse populations with low socio-economic status have additional deficits that require varied instructional strategies as well since they typically lack broad frames of reference for lessons geared to middle class students and are usually behind their peers in verbal and non verbal language skills and vocabulary development. Serving these students additionally requires teachers to implement instructional adaptations and strategies that promote student success.

NCLB mandates that schools hire highly qualified teachers or provide training to help existing teachers reach highly qualified status. Some ways of reaching this standard are through professional development, Teacher Quality State Grants, and securing government funds to hire consultants to conduct teacher training sessions. In light of federal demands, administrators are developing strategies to increase the number of highly qualified teachers within their districts and schools. For example, Georgia allocates money from Title II funding to conduct teacher training workshops (Imas, 2004). Regardless of the strategies employed, the challenge for administrators is to increase their knowledge and skills to meet federal demands and accommodate diverse populations of students with special needs (Crockett \& Kauffman, 1998).

\section{Monitoring Students}

One way administrators can evaluate teacher performance, relative to diverse students with disabilities, is by examining the amount of student monitoring that teachers provide in the classroom (Schumm \& Vaughn, 1997). Students with disabilities are often too embarrassed to elicit teacher feedback or ask questions, so teachers must continually check for understanding (Nelson-LeGall, 1985). Continuously measuring students' understanding of lessons, assignments, or tests is essential to ensuring students' understanding of the concepts presented and mastery of skills taught.

Awareness of the aforementioned concepts, along with perceived needs from the field, indicated that action, in the form of specialized education for school administrators in dealing with the special needs of diverse populations of students, needed to be taken. The following paragraphs delineate how a normative approach, in the form of an action research model, was used to create an administrative license with a special education endorsement. Action Research Conceptual Framework for Program Redesign

The foundation of action research is the improvement of practice (Burnaford, 1996). Action research in education is based upon liberation from ideas imposed on schools solely from outside and seen as an alternative to empirical analytical research (Carr \& Kemmis, 1986). It cannot be done in a laboratory setting and, as a result, must be field-based research. The concept is not new. It originated in Lewin's (1947) work on the dynamics of social change in the United States in the 1940s (Baskerville, 1999; Cohen, Manion, \& Morrison, 2000; Lewin, 1947). In a sense, action research constitutes an acknowledgment that education belongs to educators, and that they, as experts on educational practice, are the ones most able to understand and refine their work.

The predominant model of action research is an ongoing cycle of action that takes place in a spiral fashion using a logical process (Barnes, 1992; McTaggart, 1982; Zuber-Skerrit, 1992). The modified action research model used in this project included the cycles of reflection, planning, acting, observing/evaluating, and replanning (Figure $1)$. 
Figure 1. Action Research Model used as the conceptual framework for program redesign.

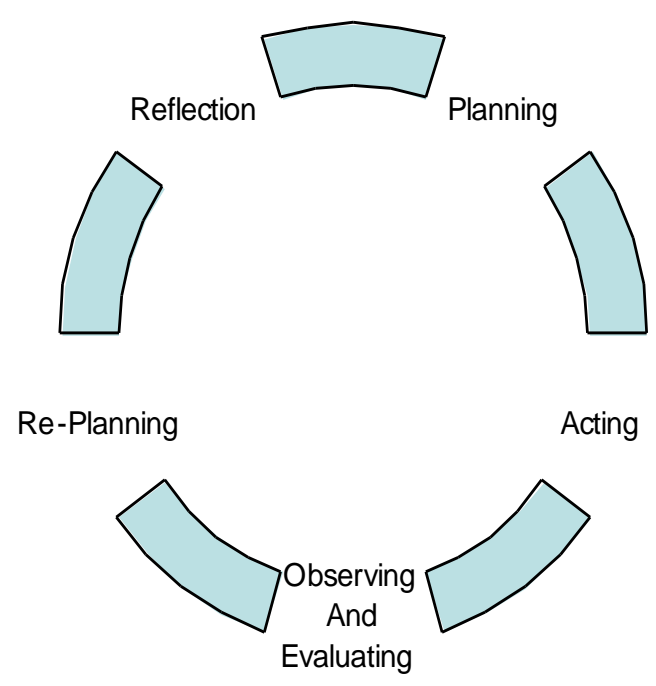

Action research was selected for this project because it fulfilled four essential professional needs: a) the need for the research to be relevant; b) the need for the researcher to be involved in the research; c) the need for the research to help improve departmental effectiveness, and d) the need for the research to stimulate reform in educational administration to ultimately meet the needs of diverse populations of special needs students..

\section{Reflection}

The input of faculty members is essential to any process of departmental reorganization. Kincheloe (1991) states "only when we as researchers are able to rescue wisdom from the cult of the expert will we control our own professional destinies" (p. 198). Faculty input is essential to the "buy in" of any programmatic change if they are to become stakeholders and true stewards of the department's vision (Deming, 1986).

In the fall of 2004, the Department of Educational Leadership and Research (ELR) began a self-evaluative process for the National Council for Accreditation of Teacher Education (NCATE) using the conceptual framework developed by the Educational Leadership Constituent Consortium (ELCC), which outlines standards for advanced programs in educational leadership (National Council for the Accreditation of Teacher Education, 2005). The framework developed included six to eight program assessments (developed by ELR) based upon standards established by ELCC under the "umbrella" of NCATE. These program assessments included The School Leaders Licensure Assessment, a comprehensive exam, an action research project, a school improvement plan, a school- 
based strategic plan, a school-based internship, and a graduate survey. Program assessments were then linked to 22 ELCC standards including the ones specifically addressing issues associated with and meeting the needs of diverse special populations of students.

Each year ELR faculty members review the above referenced assessment data. Based upon this information, they formulate both long and short-term program plans. When assessment data were reviewed during the fall of 2005, the professors determined that ELR students, future school administrators, were not mastering standards associated with diverse special education populations. With the mandate by the NCLB legislation that all subgroups of students make adequate yearly progress, and the realization that this area was a program deficiency, the initiation of the next step found in action research—planning — began.

\section{Planning}

During regular faculty meetings and meetings of the ELR Advisory Committee (composed of practicing superintendents and principals, students, State Department of Education and Institutes of Higher Learning personnel, and professors) throughout the year, all aspects of the ELR program were reviewed, discussed, and modified to obtain compliance with ELCC standards. Nominal group techniques were used as a basic structure for decision making supported with regular reports, including multiple drafts of potential plans of action (Moon, 1999). Planning efforts were manifested and organized around the specific ELCC standards addressing diversity. Standard 2.0, for example, states that successful educational leaders must be able to identify, clarify, and address barriers to student learning and communicate the importance of developing learning strategies for diverse populations (National Council for the Accreditation of Teacher Education 2005). More specifically, Standard 2.2 requires that administrative candidates demonstrate the ability to make recommendations regarding the design, implementation, and evaluation of a curriculum that fully accommodates learners' diverse needs (National Council for the Accreditation of Teacher Education 2005). In addition, the planning process included program reviews of other ELR programs around the United States, course syllabi addressing diverse populations of students found within other ELR programs, and existing course and activity sequencing currently existing within the program. As a result of planning efforts, stakeholders determined that a new course sequence and subsequent state department of education endorsement to existing school administrators' certification should be established centered around special education administration to meet the needs of diverse populations of students with learning challenges.

\section{Acting}

A new course sequence was created by inserting special education courses addressing the needs of diverse special populations, and that aligned with the critical factors of effective school leadership identified earlier in this work, into the school administrator's certification program. These courses addressed the following special education skills and competencies: application of qualitative research methodology in the context of investigations in curriculum and instruction, law, learning disabilities, school discipline policies/procedures, individualized educational programs, the interdependent contributions of relevant disciplines in training, service, and research, methods for changing behaviors of diverse individuals with disabilities; formal and informal assessment techniques, including diagnostic-prescriptive teaching strategies, the organization and administration of programs for exceptional children, in-service training units, conference planning, workshop, parent and national organizations, and an internship.

Students with school administrator certification would be awarded their specialist degree upon completion of the courses, and students without their school administrator certification would be awarded their doctorate upon completion of the courses (Figure 2). 
Figure 2. Special Education Administration Course Endorsement Sequence

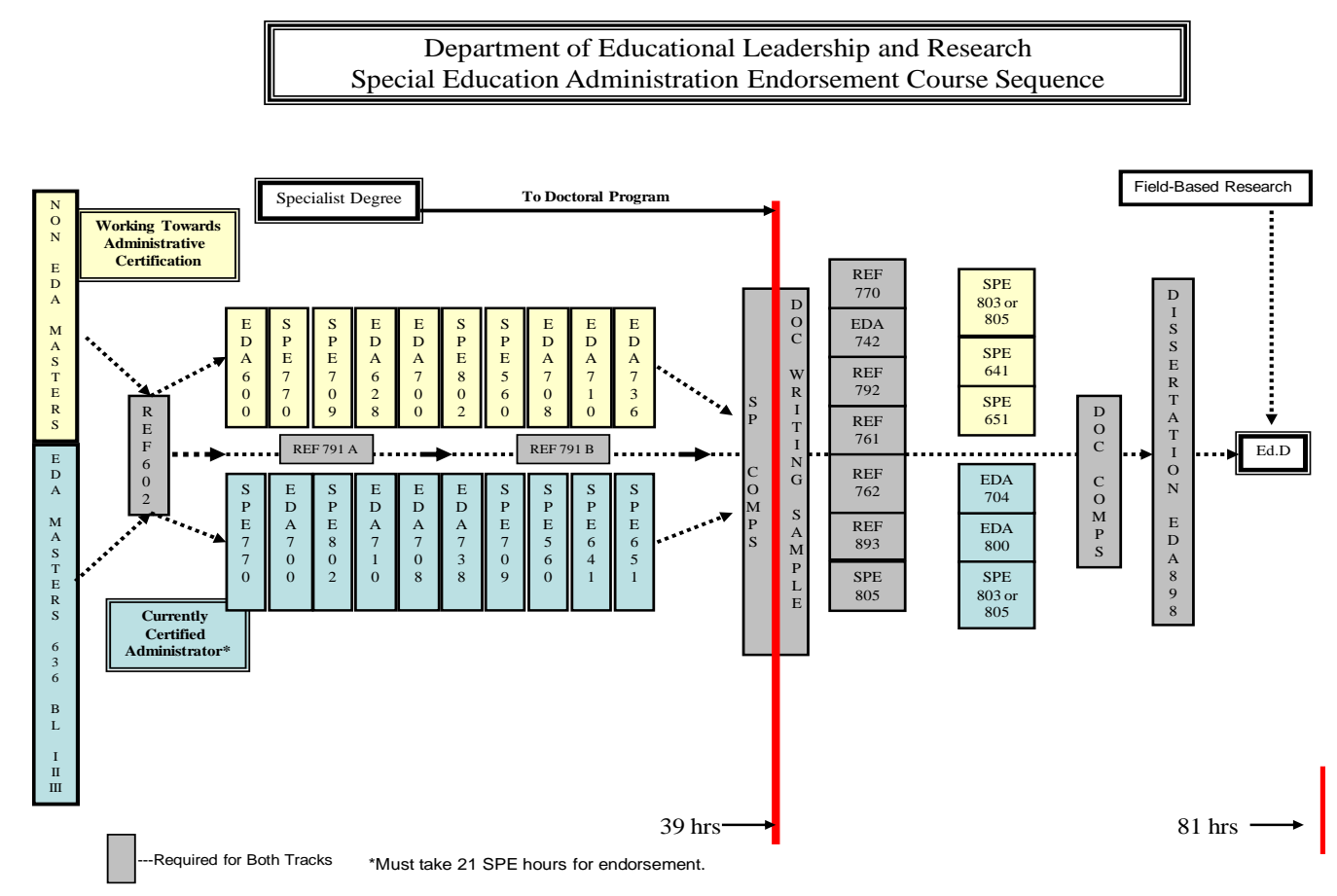

Curriculum and Instruction (CISE)

790. Qualitative Research in Curriculum and Instruction.

809. Program Evaluation and Grant Writing in Special Education.

Educational Administration (EDA)

600. Introduction to Educational Leadership

700. Public School Finance

708. Developing and Managing Human Resources

736. Practicum in Educational Administration

742. Consensus Decision-Making in Education

800. Seminar: Theories in Educational Organization and Administration

$\underline{\text { Research and Foundations (REF) }}$

602. Introduction to Educational Statistics

762. Advanced Regression Analysis

791. Applied Research

893. Advanced Educational Research

$\underline{\text { Special Education (SPE) }}$

560. Characteristics and Education of Gifted Students

651. Advanced Methods in Behavioral Management

for Individuals with Disabilities

802. Public Relations, Service, and Leadership in Special Education

805. Planning, Program Evaluation, and Policy

Analysis for Persons with Exceptional Needs.
628. Contextual Dimensions of the Principalship

704. School Community Relations

710. School Law

738. Practicum in Supervision

755. The Superintendency

761. Experimental Design

770. Evaluation Design and Methodology

889. The Dissertation Process

641. Vocational Education for Individuals with Disabilities 709. Assessment of Exceptional Individuals

770. Administration and Supervision of Programs for Exceptional Children 
Before acting, permission had to be secured from various administrative entities, including the College Council, the Professional Education Council, and the Graduate Councils. Presentations were made before these groups, and they gave their unconditional approval and overwhelming support. A number of formal and informal meetings were then held with students to share particulars of the new program. They, too, received the information with great enthusiasm and noted that if new and practicing administrators have more knowledge about meeting the needs of diverse student populations, perhaps they could increase these students' achievement levels to be in compliance with NCLB's demands.

\section{Observing And Evaluating Programmatic Structure}

On the basis of Lewin's (1947) studies on group interaction, three stages of change exist: unfreezing, changing, and freezing. Unfreezing is an initial period where people feel threatened by new ideas. This is a period of discomfort, where much support is necessary to help people receive these new ideas. The second stage, changing, is characterized by participation in new ways of doing things. Refreezing, the third stage, attempts to lock the new ideas into one's repertoire. It is difficult to see where one stage ends and another begins, and we must realize that people do not automatically move from one stage to another. Some get stuck, others race by, and still others wait for help.

The success of this program design hinges upon unfreezing the current culture of administrator preparation and making those changes necessary to ensure the success of the program. If the synergistic character of the department is not adequately acknowledged, faculty and students become frustrated by organizational paralysis and future change will be inhibited no matter how needed or important the change might have been (Sizer, 1991). As with any change, there must also be a realization that with change comes a certain amount of chaos that must be tolerated (Deal \& Kennedy, 1982). The most significant change will be that educational leadership and special education professors will be required to work collaboratively to ensure connectivity between those concepts related to leadership and special education of diverse populations of students. While no reason exists to believe that these professors will resist, their concerns must be addressed and department chairs must be willing to support them by remedying any logistical or other problem that may inhibit the development of the program.

The literature of organizational redesign suggests that the chances of successful implementation of change are greatly improved with the involvement of stakeholders, especially those who will be delivering the changes and those who will be affected by the changes (Bowers, 1990; Levine, 1991). This claim was confirmed by this undertaking. These authors concur that as a result of faculty, student, and practitioner involvement, the special education administration program will be a remarkable success as well as increase the student achievement levels of diverse populations of students in the school districts in which prospective graduates of this program will work.

\section{Expert Evaluation}

An evaluative method called Heuristic evaluation was developed by Jakob Nielsen and Rolf Molich (Nielsen, 1994). This method involves measured judgment of interface compliance based on recognized usability principles by expert evaluators. The concept of assembling expert evaluators to measure pre-determined standards was adapted to fit this process. Members of the state's Special Education and Leadership and Professional Development departments evaluated the plan, made suggestions and gave approval relative to program participants receiving state-wide endorsement from their licensure division. A university professor who had served as special education director in a school district with diverse populations of learning disabled students also gave support for the programmatic changes. In addition, three supervisors of school district special education programs, three schoollevel administrators, and five district superintendents, were asked to evaluate this endorsement proposal based upon criteria developed around the selected beliefs and standards of the Council of Administrators of Special Education (http://www.casecec.org/). Their responses are quantitatively noted in Table 1. (See Attachment \#1 for the survey instrument.) 
Table 1

Responses of expert evaluators used to review program proposal

\begin{tabular}{|c|c|c|c|c|c|}
\hline Question \# & $\begin{array}{c}\text { \% Strongly } \\
\text { Agree }\end{array}$ & \% Agree & $\%$ Neutral & $\%$ Disagree & $\begin{array}{c}\text { \% Strongly } \\
\text { Disagree }\end{array}$ \\
\hline 1. & 36 & 64 & 0 & 0 & 0 \\
\hline 2. & 36 & 64 & 0 & 0 & 0 \\
\hline 3. & 55 & 35 & 10 & 0 & 0 \\
\hline 4. & 55 & 35 & 10 & 0 & 0 \\
\hline 5. & 55 & 35 & 10 & 0 & 0 \\
\hline 6. & 55 & 35 & 10 & 0 & 0 \\
\hline 7. & 50 & 50 & 0 & 0 & 0 \\
\hline 8. & 45 & 55 & 0 & 0 & 0 \\
\hline 9. & 55 & 35 & 10 & 0 & 0 \\
\hline 10 & 45 & 45 & 10 & 0 & 0 \\
\hline 11. & 64 & 27 & 9 & 0 & 0 \\
\hline 12. & 27 & 54 & 9 & 9 & 0 \\
\hline 13 & 45 & 55 & 0 & 0 & 0 \\
\hline 14. & 55 & 45 & 0 & 0 & 0 \\
\hline 15. & 45 & 55 & 0 & 0 & 0 \\
\hline
\end{tabular}

Questions 1 and 2 specifically asked if the program encouraged the understanding of diverse populations of students and the promotion of the development of special education students reaching their maximum learning potentials. As reflected in Table 1,36\% strongly agreed and 64\% agreed, totaling 100\%--an overwhelming agreement that programmatic changes in educational leadership would positively affect diverse populations of learning disabled children.

One area of concern, however, was survey item 16 , which requested additional comments regarding the proposal. The respondents' quotes follow.

"I am concerned that the students who enroll in this program of studies may not possess the prerequisite skills they need to perform satisfactorily in two courses: SPE 641 \& SPE 651."

"I had some questions about why SPE 560 (Characteristics and Education of Gifted Students) was included in the course sequence; also the title of SPE 641 (Vocational Education in Mental Retardation) is not appropriate. It limits SPED populations that require these services to one disability."

\section{Replanning}

Based upon formal and informal feedback from the College Council, Professional Education Council, Graduate Council, and ELR and Special Education faculty, the initial proposal was modified by adding CISE 809, SPE 641, SPE 651, SPE 560 and SPE 805 to the sequence and dropping three other special education courses. It was also recommended by ELR faculty that this endorsement be integrated into the P-12 Practitioners' track Ed.D. degree program. Additionally, based upon input from special education faculty, the course content of SPE 641 and SPE 651 was reviewed to ensure curricular connection to current issues of diverse student populations with disabilities. Also, it was deemed important by special education faculty to include course preparation (SPE 560) pertaining to those students identified as academically gifted.

Data provided by the "expert evaluators" was extremely positive with the exception of responses to Question \#12. As a result, curricular modifications were made to ensure that the training helps future school leaders understand and be able to promote self-determination and independence of their special populations' students. Responses to Item \#16 indicated a concern for the ability of administrative candidates to perform satisfactorily in two SPE courses. As a result, if it is determined by mastery assessments that students are, in fact, having difficulty with these courses, an additional SPE course will be included in the program design to better prepare candidates. 
Other responses to Item \#16 expressed a concern for the need for SPE 560 (Characteristics and Education of Gifted Students) and the title of SPE 641 (Vocational Education in Mental Retardation). It was determined by special education faculty that the gifted student population continues to increase as administrators in this area are currently lacking expertise. The concern regarding SPE 641 was addressed by broadening the course to include diverse populations of students with any disability.

\section{FINAL REFLECTIONS}

Currently, no distinguishing factors for levels of special education administrator certification exist for the state in which this project was undertaken. As such, it was the opinion of the ELR department that adding a special education administration endorsement, now sanctioned by the state's department of education, would help administrative candidates by providing them with expertise to meet the needs of diverse student populations with disabilities. Better prepared administrators will also indirectly and directly improve the quality of service to these students and possibly enable districts to meet the increased accountability demands placed upon them by NCLB.

As with other program redesign projects, the reorganization process described in this work was long and intense with much dialogue among faculty members, practitioners, and students. Although change can be uncomfortable, the change described in this work was rewarding in that it clearly benefited both administrative candidates and the state's diverse populations of P-12 students with learning challenges.

Another refreshing outcome of the self-evaluative process initiated by ELCC was seeing the professors "practice what they preached" in terms of shared decision-making and building consensus within both the ELR and CISE departments. Because of their involvement, faculty members in both departments embraced decisions and the process, albeit, at times, laborious. In addition, the intense interaction has helped professors have a greater respect for each other and a stronger appreciation of their respective disciplines. The process has also promoted enhanced working relationships among faculty members within the department of educational leadership.

Many school administrators are concerned about their level of preparation, most notably in the area of Special Education of diverse students (DiPaola \& Tschannen-Morgan, 2004). This concern may also be a significant contributing factor to the current shortage of administrators (Olson, 1999). The endorsement described in this work may help alleviate administrators' concerns while making them more comfortable and competent to make decisions impacting their diverse populations of students with special needs. In effective curriculum integration models, knowledge is meaningfully related and connects in such a way that it is relevant to other areas of learning as well as to real life (Morris, 2003). Not only is this program change relevant to other areas of learning by prospective school administrators, but it also has the potential to affect the lives of the diverse populations of special needs' students they will serve.

\section{REFERENCES}

1. Baker, E., Wang, M., \& Walberg, H. (1994). The effects of inclusion on learning. Educational Leadership, 52, 33-35.

2. Barnes, D. (1992). The significance of teachers' frames for teaching. In T. Russell \& H. Munby (Eds.), Teachers and teaching: From classroom to reflection (pp. 9-32). New York: The Falmer Press.

3. Baskerville, R. L. (1999). Investigating information systems with action research. Communications of the Association for Information Systems, 2 (Article 19) http://cais.isworld.org/articles/2-19/

4. Bowers, B. (1990, April). Initiating change in schools. National Association of Elementary School Principals, p.1.

5. Burnaford, G. (1996). A life of its own: Teacher research and transforming the curriculum. In G. Burnaford, J. Fischer, \& D. Hobson (Eds). Teachers doing research: Practical possibilities (pp. 57-81). Mahway, New Jersey: Lawrence Erlbaum Associates.

6. Carr, W., \& Kemmis, S. (1986). Becoming critical: Education, knowledge and action research. Philidelphia: The Falmer Press. 
7. Cohen, P., Forgan, J. W., Klinger, J. K., Schumm, J. S., \& Vaughn, S. (1998). Inclusion or pull-out: Which do students prefer? Journal of Learning Disabilities, 31(2), 29-38.

8. Cohen, L., Manion, L., \& Morrison, K. (2000). Research methods in education. (5 ${ }^{\text {th }}$ ed.). London: RoutledgeFalmer.

9. $\quad$ Crockett, J. B., \& Kauffman, J. M. (1998). Taking inclusion back to its roots. Education Week, 24(28), 2224.

10. Council of Administrators of Special Education. http://www.casecec.org/.

11. Deal, T. E., \& Kennedy, A. A. (1982). Corporate cultures. Reading, MA: Addison-Wesley.

12. Deming, W. E. (1986). Out of the crisis. Cambridge, MA Massachusetts Institute of Technology Press.

13. Dick, B. (1999). What is action research? [Online] Available: http://www.scu.edu.au/schools/gcm/ar/whatisar.html

14. DiPaola, M., \& Walther-Thomas, C. (2003). Principals and special education: The critical role of school leaders. Retrieved May 10, 2006, from http://www.coe.ufl.edu/copsse/docs/IB-7/1/IB-7.pdf

15. DiPaola, M., \& Tschannen-Morgan, M. (2004, April). The principalship at a crossroads: A study of the conditions and concerns of principals. The Bulletin, 87, (634), pp. 43-65.

16. Hehir, T. (2003). Beyond inclusion: Educators' ableist assumptions about students with disabilities compromise the quality of instruction. The School Administrator, 60(3), 36-40.

17. Imas, K. (2004). Implementing No Child Left Behind. State News, 12-13, 36.

18. Kincheloe, J. L. (1991). Teachers as researchers: Qualitative inquiry as a path to empowerment. London: The Falmer Press.

19. Levine, D. (1991, January). Creating effective schools: findings and implications from research and practice. Phi Delta Kappan, pp. 389-393.

20. Lewin, K. (1947). Group decisions and social change. Troy, MO.: Holt, Rinehart \& Winston.

21. McTaggart, R. (1982). The action research planner. Geelon, Victoria, Australia: Deakin University Press.

22. Morris, Robert C. (2003). A guide to curricula integration. Kappa Delta Pi Record. Summer 2003.

23. Nelson-LeGall, S. (1985). Help-seeking behavior in learning. In E. W. Gordon (Ed.). Review of research on education (Vol. 12, pp. 55-90). Washington, DC: American Educational Research Association.

24. Nielsen, J. (1994). Heuristic evaluation. J. Nielsen \& R. L. Mack, (Eds.) Usability inspection methods. New York: John Wiley \& Sons.

25. National Council for the Accreditation of Teacher Education (2005). Educational Leadership Constituent Consortium Standards, www.ncate.org/

26. Olson, L. (1999). Demand for principals growing, but candidates aren't applying, Education Week on the Web, http://www.edweek.com/ew/vol-18/25prin.h18.

27. Rallis, S. F., \& Anderson, G. (1998). Building inclusive schools: Places where all children can learn. Andover, MA: The Regional Laboratory.

28. Schumm, J. S., \& Vaughn, S. (1997). Are they getting it? How to monitor student understanding in inclusive classrooms. Intervention in School \& Clinic, 32(3), 168-172.

29. Sizer, T. (1991). No pain, no gain. Educational Leadership, 47(5), pp. 32-34.

30. United States Department of Education (1995) Extending Learning Time for Disadvantaged Students Volume 1 Summary of Promising Practices. (Online), http://www.ed.gov/pubs/Extending/vol1/execsumm.html

31. Vaughn, S. \& Schumm, J. S. (1994). Middle school teachers' planning for students with learning disabilities. Remedial \& Special Education, 15(3), 18-24.

32. Vaughn, S., \& Schumm, J. S. (1995). Responsible inclusion for students with learning disabilities. Journal of Learning Disabilities, 28(5), 264-270.

33. Vaughn, S., Schumm, J. S., Klingner, J., \& Saumell, L. (1995). Students' views of instructional practices: Implications for inclusion. Learning Disability Quarterly, 18, 236-248.

34. Villa, R. A., \& Thousand, J. S. (2003). Making inclusive education work: Successful implementation requires commitment, creative thinking, and effective classroom strategies. Educational Leadership, 61(2), 42-56.

35. Yell, M. L., \& Shriner, J. G. (1997). The IDEA amendments of 1997: Implications for special and general education teachers, administrators, and teacher trainers. Focus of Exceptional Children, 30(1), 19-25. 
36. Zaretsky, L. (2004). Responding ethically to complex school-based issues in special education. International Studies in Educational Administration, 32(2), 63-77.

37. Zuber-Skerrit, O. (1992). Action research in higher education. London: Kogan Page.

\section{ATTACHMENT \#1}

\section{Department of Educational Leadership and Research Special Education Administration Endorsement Evaluation of Proposal}

This survey is being conducted to ascertain feedback regarding the attached Special Education Administration Endorsement proposal. This data will be used to help determine any program modifications prior to submission. Your cooperation is greatly appreciated and your anonymity will be assured. Returning the completed survey implies consent for your participation. Thank you for your input.

Please call Dr. XXXXXXXXX, Department Chair, at XXXXXXXXXX if you have any additional questions.

\section{Please circle your responses}

Current Position: EDA Professor University Administrator Superintendent Principal Supervisor Supervisor of Special Education Other

In which system are you currently employed? Public $\quad$ Private (non-parochial) Parochial N/A

1. This program encourages the understanding of diversity.

$$
\text { Strongly Agree Agree Neutral Disagree Strongly Disagree }
$$

2. This program promotes the development of special education student's maximum potential.

$$
\text { Strongly Agree Agree Neutral Disagree Strongly Disagree }
$$

3. This program helps administrators understand their importance as change agents.

$$
\text { Strongly Agree Agree Neutral Disagree Strongly Disagree }
$$

4. This program helps administrators understand the impact they have on the quality and future of the lives of special education students and their families.

$$
\text { Strongly Agree Agree Neutral Disagree Strongly Disagree }
$$

5. This program represents an innovation in the field of special education.

Strongly Agree Agree Neutral Disagree Strongly Disagree

6. This program helps develop a sense for serving and supporting special education students.

Strongly Agree Agree Neutral Disagree Strongly Disagree

7. This program embraces current professional practice.
Strongly Agree
Agree
Neutral
Disagree
Strongly Disagree 
8. This program supports study and research guided by the conventions of scholarly inquiry.

$$
\text { Strongly Agree Agree Neutral Disagree Strongly Disagree }
$$

9. Programming includes elements regarding the privacy of students and parents in accordance with State/Provincial and Federal laws.

Strongly Agree Agree Neutral Disagree Strongly Disagree

10. This program promotes the development of respect, courtesy, and fairness.

Strongly Agree Agree Neutral Disagree Strongly Disagree

11. This program upholds and advances the values, ethics knowledge and mission of the profession.

$$
\text { Strongly Agree Agree Neutral Disagree Strongly Disagree }
$$

12. This program promotes, fosters and supports maximum self-determination and independence on the part of exceptional children.
Strongly Agree Agree
Neutral
Disagree
Strongly Disagree

13. This program emphasizes impartial professional judgment in evaluating the needs of exceptional children and their parents.
Strongly Agree Agree
Neutral
Disagree
Strongly Disagree

14. This program develops an understanding of the responsibility of administrators to provide meaningful training experiences to colleagues, general educators, and the public.
Strongly Agree Agree
Neutral
Disagree
Strongly Disagree

15. This program promotes the general welfare of exceptional children.
Strongly Agree Agree
Neutral
Disagree
Strongly Disagree

16. Additional comments regarding the proposal. 